\title{
Vitiligo: The Association With Metabolic Syndrome and the Role of Simvastatin as an Immunomodulator
}

Deepak Verma ${ }^{1}$, Khadija Hussain ${ }^{2}$, Karez S. Namiq ${ }^{3}$, Amena Firoz ${ }^{4}$, Manel Bouchama ${ }^{5}$, Maham Raza ${ }^{5}$, Muhammad Haris 6,5 , Safeera Khan ${ }^{5}$

1. Internal Medicine/Family Medicine, California Institute of Behavioral Neurosciences \& Psychology, Fairfield, USA 2 Radiology, California Institute of Behavioral Neurosciences \& Psychology, Fairfield, USA 3. Oncology, California Institute of Behavioral Neurosciences \& Psychology, Fairfield, USA 4. Pediatrics, California Institute of Behavioral Neurosciences \& Psychology, Fairfield, USA 5. Internal Medicine, California Institute of Behavioral Neurosciences \& Psychology, Fairfield, USA 6. Internal Medicine, Royal Lancaster Infirmary, Lancaster, GBR

Corresponding author: Deepak Verma,dv41908@gmail.com

\begin{abstract}
Vitiligo is an autoimmune condition primarily affecting the skin where there is destruction of melanocytes characterized by pinkish-white patches on the skin. It is associated with other autoimmune diseases such as thyroid disease, rheumatoid arthritis, diabetes mellitus, and metabolic syndrome. Metabolic syndrome is a constellation of disorders including insulin resistance, hypertension, dyslipidemia, and obesity, and is considered a leading cause of cardiovascular morbidity. Simvastatin is a potent hypolipidemic drug that also possesses immunomodulating properties and is a common drug used in dyslipidemia and cardiovascular diseases. This study aimed to assess the association between vitiligo and metabolic syndrome and explore the immunomodulating properties of simvastatin for use in vitiligo.
\end{abstract}

We reviewed various articles from PubMed, ResearchGate, and Google Scholar using different keywords and Medical Subject Headings and finalized 33 studies to be used in our review. The articles selected showed a positive association between vitiligo and metabolic syndrome or one of the component diseases of metabolic syndrome. The benefits of using simvastatin were also addressed by few articles attributing to its antioxidant and immunomodulating effect. However, there was no concrete explanation justifying the association between vitiligo and metabolic syndrome due to a limited number of studies and smaller sample size. Large-scale clinical trials should be conducted to evaluate the use of simvastatin as an immunomodulator in vitiligo to prevent possible metabolic complications.

Received 02/20/2021 Review began 03/10/2021 Review ended 03/17/2021 Published 03/22/2021

๑) Copyright 2021 Verma et al. This is an open access article distributed under the terms of the Creative Commons Attribution License CC-BY 4.0., which permits unrestricted use, distribution, and reproduction in any medium, provided the original author and source are credited.
Categories: Dermatology, Endocrinology/Diabetes/Metabolism, Internal Medicine

Keywords: metabolic syndrome, vitiligo, dyslipidemia, hypertension, obesity, simvastatin

\section{Introduction And Background}

Vitiligo is an acquired pigmentation disorder of the skin in which there is destruction of melanocytes. It is characterized by white patches on the skin. Around $0.1-2 \%$ of the world's population is affected by the disease, irrespective of race and sex [1]. The disorder has been reported to have a high incidence in the second and third decade of life [1].

Vitiligo is classified into segmental and non-segmental vitiligo [2]. Non-segmental vitiligo is usually bilateral and symmetrical in distribution. Segmental vitiligo is unilateral and focal in distribution [2]. The etiopathogenesis of vitiligo involves various factors, which include oxidative stress [3], autoimmune destruction of melanocytes, neural hypothesis through an accumulation of a neurochemical substance that decreases melanin production, and sympathetic nervous system activity through direct cytotoxic effect and indirectly through the generation of free radicals $[2-4]$.

The clinical course of vitiligo can be assessed using the Vitiligo Area Severity Index (VASI) and Vitiligo Disease Activity Score (VIDA) score. In general, vitiligo patients lead a normal healthy life. Still, some patients are at an increased risk of developing various systemic diseases such as thyroid disease, Addison's disease, systemic lupus erythematosus, rheumatoid arthritis, diabetes, and metabolic syndrome [5].

A metabolic syndrome is a group of disorders related to the body's metabolism, including diabetes, hypertension, obesity, and dyslipidemia. The National Cholesterol Education Program Adult Treatment Panel III defined metabolic syndrome as the presence of any three of the following five characteristics [6]:

1. Abnormal obesity defined as waist circumference of $102 \mathrm{~cm}$ in males and $88 \mathrm{~cm}$ in females.

2. Serum triglyceride level of $150 \mathrm{mg} / \mathrm{dL}$ or drug treatment for elevated triglyceride. 


\section{Cureus}

3. Serum high-density lipoprotein (HDL) cholesterol level of $<40 \mathrm{mg} / \mathrm{dL}$ in males and $<50 \mathrm{mg} / \mathrm{dL}$ in females or drug treatment for low HDL cholesterol.

4. Blood pressure of 130/85 $\mathrm{mmHg}$ or drug treatment for elevated blood pressure.

5. Fasting plasma glucose level of $100 \mathrm{mg} / \mathrm{dL}$ or drug treatment for elevated blood glucose.

While insulin resistance is believed to be the major factor involved in developing metabolic syndrome [7], oxidative stress has been suggested to cause the disorder by some studies [3]. Metabolic syndrome has become increasingly prevalent, with one-quarter of the adult population being affected [1]. Metabolic syndrome is associated with an increased risk of myocardial infarction, stroke, and diabetes [7]. Figure 1 depicts the risk factors associated with metabolic syndrome.

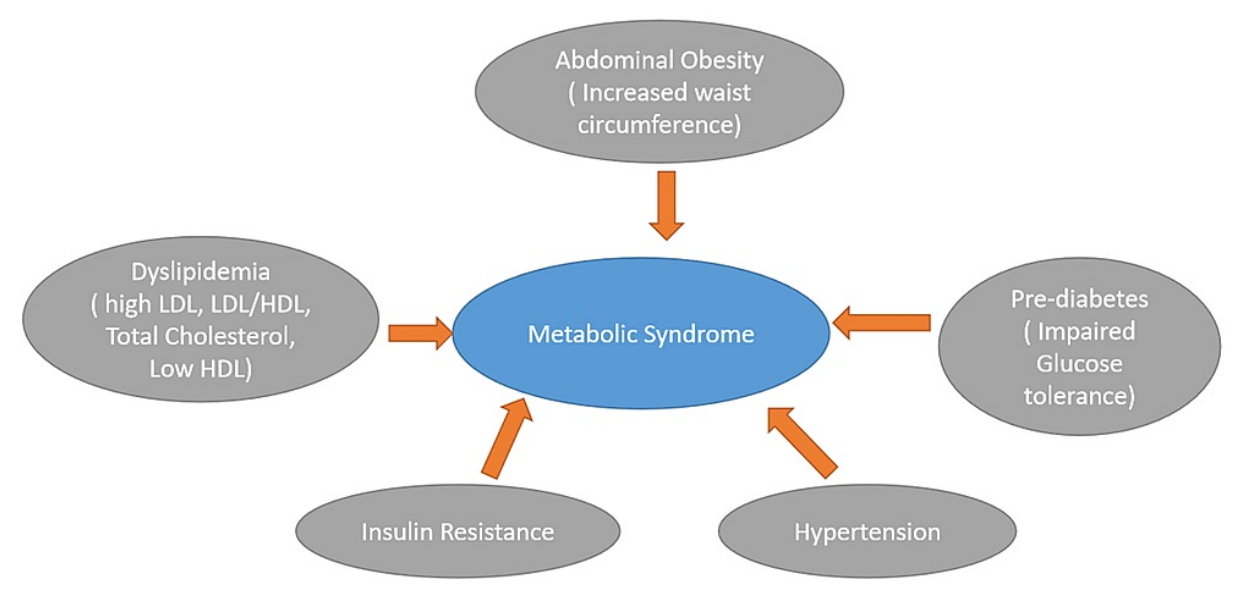

FIGURE 1: Risk factors associated with metabolic syndrome.

LDL: low-density lipoprotein; HDL: high-density lipoprotein

Simvastatin is a potent statin drug that inhibits 3-hydroxy-3-methylglutaryl coenzyme-A (HMG-CoA) reductase enzyme involved in cholesterol synthesis in the liver. It is a widely used drug for the treatment of dyslipidemia and cardiovascular diseases [8]. Isoprenoids are formed during cholesterol biosynthesis, which is known to induce inflammation via the intracellular second messenger system. Simvastatin, by inhibition of HMG-CoA reductase, helps prevent the generation of isoprenoids [9]. In addition, it directly inhibits CD8+ T-cells specific to melanocytes, which leads to limited proliferation and decreased interferon gamma (IFN- $\gamma$ ) production [10]. We will further try to analyze whether simvastatin can be used as an immunomodulating agent in vitiligo.

Some studies have shown the association between vitiligo and diabetes or hypertension or dyslipidemia based on smaller sample size. This systematic review explores the association between vitiligo and metabolic syndrome and explores the possibility of using simvastatin as an immunomodulator in vitiligo to prevent metabolic complications.

\section{Review}

\section{Method}

Electronic Search

We followed the Preferred Reporting Items for Systematic Review and Meta-Analysis (PRISMA) guidelines for conducting our review [11]. We systematically searched PubMed, ResearchGate, and Google Scholar for relevant studies. Studies published from inception to 2021 were identified. The keywords metabolic syndrome, vitiligo, dyslipidemia, hypertension, obesity, and simvastatin were used either alone or in combination to search the articles. A manual search was also performed by going through the reference list of a few articles.

Inclusion and Exclusion Criteria

There was no language barrier. Articles published in English, Turkish, and Chinese were included. The studies that met the following criteria were included: (a) provided information regarding the association between vitiligo and metabolic syndrome, and (b) explained about the associated factors common to both 


\section{Cureus}

disorders. Exclusion criteria were animal trials, duplicate data, irrelevant information to any of the disorders, or insufficient information.

Data Extraction

Data were extracted using a standard data abstraction form. Relevant papers were reviewed independently, and any difference of opinions were resolved through mutual discussion. The following information was drawn out: first author's name, year of publication, number of cases and controls, number of vitiligo patients having associated metabolic disorders, and number of patients participating in the clinical trials conducted. Figure 2 depicts the PRISMA flow diagram showing the methodology.

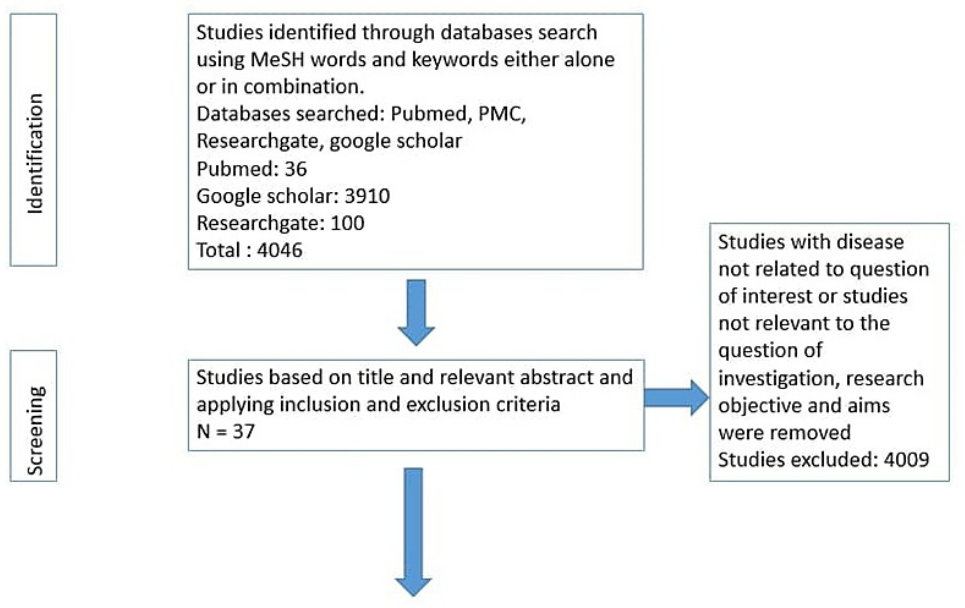

\begin{tabular}{|c|c|}
\hline 胥 & $\begin{array}{l}\text { Articles were assessed for eligibility by quality } \\
\text { appraisal using quality assessment tool. } \\
\text { Randomized Controlled Trial: Cochrane risk of } \\
\text { bias assessment tool } \\
\text { Observational Studies: Newcastle ottawa scale } \\
\text { Systematic review and meta-analysis: PRISMA } \\
\text { checklist } \\
\text { Case report: JB Checklist } \\
\text { In-vitro experiments: IV-CAT } \\
\text { Literature review: SANRA }\end{array}$ \\
\hline 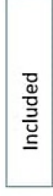 & $\begin{array}{l}\text { Studies retained: } 33 \\
\text { Randomized Controlled Trials: } 3 \\
\text { Cross-sectional: } 4 \\
\text { Case-control: } 18 \\
\text { Case-report: } 1 \\
\text { In-vitro experiment: } 1 \\
\text { Literature review: } 3\end{array}$ \\
\hline
\end{tabular}

\section{FIGURE 2: PRISMA flow diagram showing the methodology.}

PMC: PubMed central; PRISMA: Preferred Reporting Items for Systematic Reviews and Meta-Analysis; JB Checklist: Joanna Briggs Institute Checklist; IV-CAT: In Vitro Critical Appraisal Tool; SANRA: Scale for the Assessment of Narrative Review Article

\section{Results}

A total of 4,046 articles were screened, of which 4,009 were excluded due to the following reasons: irrelevant information, not providing sufficient information, and duplicate data. A total of 37 articles fulfilled the inclusion criteria and were incorporated in our systematic review. We assessed 37 studies for quality using standardized quality assessment tools, and 33 articles were qualified for the quality appraisal. The following tools were used:

1. Randomized controlled trials: Cochrane Risk of the Bias Assessment Tool.

2. Observational studies: Newcastle-Ottawa Scale. 
3. Case reports: Joanna Briggs Institute Checklist.

4. In-vitro experiments: In Vitro Critical Appraisal Tool.

5. Systematic reviews and meta-analyses: PRISMA checklist.

6. Literature review articles: Scale for the Assessment of Narrative Review Article.

Our review article included 1,315 vitiligo patients from 20 different observational studies, 1,600 patients of type 2 diabetes mellitus from two cross-sectional studies, 127,589 patients from three systematic reviews and meta-analyses, 44 patients from three clinical trials, and one patient from a case report.

\section{Discussion}

Various studies have shown the association between vitiligo and metabolic syndrome. While there have been various factors involved in developing both disorders, we will discuss a few areas that will help establish the association.

Role of Oxidative Stress

Oxidative stress has been a notorious factor involved in the development of various diseases, including vitiligo and metabolic syndrome, through the generation of reactive oxygen species (ROS). ROS plays a vital role in cellular events such as inflammatory response, cell growth alteration, and apoptosis [12]. Enzymatic and non-enzymatic antioxidants such as superoxide dismutase, glutathione peroxidase, and catalase are present in melanocytes whose primary function is to prevent oxidative damage. ROS such as superoxide ion and peroxide $\left(\mathrm{H}_{2} \mathrm{O}_{2}\right)$ ion cause oxidative stress leading to the destruction of melanocytes via apoptosis [13]. In addition, melanocytes are found in adipose tissue, where they exert anti-inflammatory and antioxidant effects. Reduced number of melanocytes and melanogenesis leads to the development of metabolic syndrome through insulin resistance and lipid abnormalities [3].

Koca et al., in their study, showed excess free radical generation leading to peroxidative damage mediated by increased oxidative destruction of polyunsaturated fatty acid of phospholipids [14]. This oxidative destruction was supported by increased levels of malondialdehyde (MDA) and $\mathrm{H}_{2} \mathrm{O}_{2}[12,14,15]$. Azzazi et al. and Khan et al. also found decreased total antioxidant capacity in patients compared to controls. They found a significant association between carotid intima-media thickness and MDA levels [12,15]. A study by Bhatti et al. mentioned that oxidative stress caused the deposition of ROS in cells and tissues, leading to mitochondrial dysfunction by interacting with mitochondrial and cellular components such as DNA, protein, and lipids [16]. Alteration in mitochondrial functioning has been implicated in the development of metabolic syndrome due to defective cell metabolism. Increased glucose level enhances ROS overproduction leading to morphological changes in mitochondria [16]. Accumulation of lipids and free fatty acids causes the insulin signaling pathway inhibition, which majorly contributes to metabolic syndrome [16]. Table 1 summarizes the role of oxidative stress. 


\section{Cureus}

\begin{tabular}{|c|c|c|c|c|c|c|}
\hline Author & Year & $\begin{array}{l}\text { Type of } \\
\text { study }\end{array}$ & $\begin{array}{l}\text { Number } \\
\text { of } \\
\text { patients }\end{array}$ & Purpose of study & Result & Conclusion \\
\hline $\begin{array}{l}\text { Ataş et } \\
\text { al. [3] }\end{array}$ & 2017 & $\begin{array}{l}\text { Case- } \\
\text { control }\end{array}$ & 63 & $\begin{array}{l}\text { To investigate the } \\
\text { association of metabolic } \\
\text { syndrome and vitiligo }\end{array}$ & $\begin{array}{l}\text { Poor clinical features of } \\
\text { vitiligo were found to be an } \\
\text { independent factor for } \\
\text { metabolic syndrome }\end{array}$ & $\begin{array}{l}\text { Increased risk of developing } \\
\text { metabolic syndrome in vitiligo }\end{array}$ \\
\hline $\begin{array}{l}\text { Azzazi } \\
\text { et al. } \\
{[12]}\end{array}$ & 2020 & $\begin{array}{l}\text { Case- } \\
\text { control }\end{array}$ & 50 & $\begin{array}{l}\text { To determine the } \\
\text { increased risk of } \\
\text { cardiovascular events in } \\
\text { vitiligo }\end{array}$ & $\begin{array}{l}\text { Increased levels of } \mathrm{H}_{2} \mathrm{O}_{2} \\
\text { and MDA and decreased } \\
\text { levels of TAC. Increased } \\
\text { CIMT level }\end{array}$ & $\begin{array}{l}\text { Increased risk of developing } \\
\text { dyslipidemia and atherosclerosis, } \\
\text { which increases the risk of } \\
\text { developing cardiovascular diseases }\end{array}$ \\
\hline $\begin{array}{l}\text { Sinha } \\
\text { et al. } \\
\text { [13] }\end{array}$ & 2019 & $\begin{array}{l}\text { Case- } \\
\text { control }\end{array}$ & 75 & $\begin{array}{l}\text { To assess the association } \\
\text { of metabolic syndrome } \\
\text { with vitiligo }\end{array}$ & $\begin{array}{l}\text { A significant difference in } \\
\text { HDL and TG in patients } \\
\text { compared to controls }\end{array}$ & $\begin{array}{l}\text { Metabolic syndrome was associated } \\
\text { with vitiligo }\end{array}$ \\
\hline $\begin{array}{l}\text { Khan } \\
\text { et al. } \\
{[15]}\end{array}$ & 2009 & $\begin{array}{l}\text { Case- } \\
\text { control }\end{array}$ & 30 & $\begin{array}{l}\text { To determine the level of } \\
\text { antioxidants in patients }\end{array}$ & $\begin{array}{l}\text { Increased levels of MDA, } \\
\text { decreased levels of SOD, } \\
\text { GPx, vitamin C, vitamin E, } \\
\text { and TAC }\end{array}$ & $\begin{array}{l}\text { Oxidative stress plays a vital role in } \\
\text { melanocyte destruction leading to } \\
\text { the development of vitiligo }\end{array}$ \\
\hline $\begin{array}{l}\text { Bhatti } \\
\text { et. al. } \\
{[16]}\end{array}$ & 2017 & $\begin{array}{l}\text { Narrative } \\
\text { review }\end{array}$ & - & $\begin{array}{l}\text { To ascertain the role of } \\
\text { mitochondrial dysfunction } \\
\text { and oxidative stress in } \\
\text { metabolic disorders }\end{array}$ & - & $\begin{array}{l}\text { Mitochondrial dysfunctions are } \\
\text { involved in aging, cancer, metabolic } \\
\text { syndrome, and neurodegenerative } \\
\text { disorders }\end{array}$ \\
\hline
\end{tabular}

\section{TABLE 1: Role of oxidative stress.}

$\mathrm{H}_{2} \mathrm{O}_{2}$ : hydrogen peroxide; MDA: malondialdehyde; CIMT: carotid intima-media thickness; TAC: total antioxidant capacity; HDL: high-density lipoprotein; TG: triglyceride; SOD: superoxide dismutase; GPx: glutathione peroxidase

Role of Pro-Inflammatory Cytokines and Neurochemical Hypothesis

It is a well-known fact that pro-inflammatory cytokines play a major role in developing various autoimmune diseases. Patients with active vitiligo have increased pro-inflammatory cytokines like tumor necrosis factor (TNF)- $\alpha$, interleukin (IL)-6, IL-8, IL-1- $\beta$, IFN- $\gamma$, and some anti-inflammatory cytokines such as IL-5, and IL10 [17]. Inflammatory cytokines are involved in the inhibition of the insulin signaling pathway by phosphorylation of serine residues of insulin receptor substrate-1, which leads to the development of insulin resistance in vitiligo. Karadag et al. showed that Insulin resistance in vitiligo developed due to cytokines or autoimmune reaction to melanocytes [18].

Pietrzak et al. showed that adipokines and TNF- $\alpha$, IL-6, monocyte chemoattractant factor secreted from white adipose tissue during the process of glucose and lipid metabolism cause metabolic syndrome and cardiovascular diseases if any disturbance in their secretion occurs. They also showed that cytokines like TNF- $\alpha$, IL-1, IL-6, and C-reactive protein (CRP) contributed in inducing insulin resistance and other metabolic complications. Process fostering lipid peroxidation that occurs in the epidermis and adipose tissue as well is a possible rationale of lipid abnormalities in vitiligo [19].

Another aspect that can be highlighted to demonstrate the association is the neurochemical pathway. It is a well-known fact that increased catecholamine and homocysteine levels are associated with an increased risk of hypertension, a constituent of metabolic syndrome. A study by Namazi et al. showed increased catecholamines in vitiligo patients compared to the control group, which they attributed to increased levels of stress in patients [2]. A study by Cucchi et al. found increased levels of catecholamines and their metabolites [20]. In contrast, Orecchia et al. also reported increased levels of catecholamines in patients with a shorter duration of disease, which was statistically not significant in their study [21]. Taneja et al., in their study, found elevated levels of LDL cholesterol, reduced levels of HD -cholesterol, increased LDL-toHDL ratio, and increased levels of homocysteine. They concluded that the result of their study might be due to ongoing abnormal metabolic processes, and homocysteine may be a precipitating factor [22]. Increased homocysteine levels were also found in studies by Tsai et al. and Singh et al. correlating to disease activity $[23,24]$. Table 2 summarizes the role of cytokines and homocysteine. 


\section{Cureus}

\begin{tabular}{|c|c|c|c|c|c|c|}
\hline Author & Year & study & patients & study & Result & Conclusion \\
\hline $\begin{array}{l}\text { Namazi } \\
\text { et al. [2] }\end{array}$ & 2020 & $\begin{array}{l}\text { Case- } \\
\text { control }\end{array}$ & 83 & $\begin{array}{l}\text { To investigate } \\
\text { the relationship } \\
\text { between } \\
\text { hypertension } \\
\text { and vitiligo }\end{array}$ & Increased prevalence of HTN in vitiligo & $\begin{array}{l}\text { Increased prevalence of HTN in } \\
\text { vitiligo due to increased stress- } \\
\text { causing release of } \\
\text { catecholamines }\end{array}$ \\
\hline $\begin{array}{l}\text { Mitra et } \\
\text { al. [17] }\end{array}$ & 2017 & $\begin{array}{l}\text { Cross- } \\
\text { sectional }\end{array}$ & 51 & $\begin{array}{l}\text { To investigate } \\
\text { the relationship } \\
\text { between ROS } \\
\text { and cytokines in } \\
\text { patients with } \\
\text { vitiligo }\end{array}$ & $\begin{array}{l}\text { Generation of ROS was higher in } \\
\text { patients with vitiligo along with } \\
\text { increased levels of pro-inflammatory } \\
\text { cytokines }\end{array}$ & $\begin{array}{l}\text { Enhanced production of ROS- } \\
\text { mediated lipid peroxidation, DNA } \\
\text { damage, along with a decline in } \\
\text { antioxidant capacity was } \\
\text { accountable for disease } \\
\text { progression }\end{array}$ \\
\hline $\begin{array}{l}\text { Karadag } \\
\text { et al. [18] }\end{array}$ & 2011 & $\begin{array}{l}\text { Case- } \\
\text { control }\end{array}$ & 57 & $\begin{array}{l}\text { To investigate } \\
\text { the relationship } \\
\text { between vitiligo } \\
\text { and insulin } \\
\text { resistance }\end{array}$ & $\begin{array}{l}\text { Patients with vitiligo had elevated } \\
\text { HOMA-IR, insulin, and C-peptide } \\
\text { levels, increased LDL-to-HDL ratio, } \\
\text { and reduced HDL cholesterol with an } \\
\text { increase in mean SBP }\end{array}$ & $\begin{array}{l}\text { Increased insulin resistance in } \\
\text { vitiligo could be connected to } \\
\text { mechanisms other than obesity } \\
\text { like cytokine production or } \\
\text { autoimmune reaction to } \\
\text { melanocytes }\end{array}$ \\
\hline $\begin{array}{l}\text { Pietrzak } \\
\text { et al. [19] }\end{array}$ & 2014 & $\begin{array}{l}\text { Case- } \\
\text { control }\end{array}$ & 34 & $\begin{array}{l}\text { To assess lipid } \\
\text { profile in } \\
\text { vitiligo-affected } \\
\text { children }\end{array}$ & $\begin{array}{l}\text { Increased LDL, decreased HDL, and } \\
\text { increased LDL/HDL and TG }\end{array}$ & $\begin{array}{l}\text { Lipid disturbances in vitiligo } \\
\text { patients were probably due to } \\
\text { metabolic disturbances in } \\
\text { adipose tissue and oxidative } \\
\text { stress }\end{array}$ \\
\hline $\begin{array}{l}\text { Cucchi } \\
\text { et al. [20] }\end{array}$ & 2000 & $\begin{array}{l}\text { Case- } \\
\text { control }\end{array}$ & 70 & $\begin{array}{l}\text { To investigate } \\
\text { the association } \\
\text { between vitiligo } \\
\text { and } \\
\text { monoaminergic } \\
\text { system }\end{array}$ & $\begin{array}{l}\text { Levels of NE, E, NMN, MN, HVA, 5- } \\
\text { HIAA were remarkably elevated in } \\
\text { patients with vitiligo }\end{array}$ & $\begin{array}{l}\text { Higher levels of catecholamines } \\
\text { and metabolites indicate } \\
\text { increased activity of the } \\
\text { monoaminergic system, which } \\
\text { might be due to stressful events }\end{array}$ \\
\hline $\begin{array}{l}\text { Orecchia } \\
\text { et al. [21] }\end{array}$ & 1994 & $\begin{array}{l}\text { Case- } \\
\text { control }\end{array}$ & 40 & $\begin{array}{l}\text { To investigate } \\
\text { the relationship } \\
\text { between vitiligo } \\
\text { and } \\
\text { monoaminergic } \\
\text { system }\end{array}$ & $\begin{array}{l}\text { HVA and NMN levels were increased. } \\
\text { Both catecholamines and metabolites } \\
\text { showed higher concentration in } \\
\text { patients with a shorter duration of } \\
\text { disease but were statistically not } \\
\text { significant }\end{array}$ & $\begin{array}{l}\text { Monoaminergic systems were } \\
\text { unlikely to be related to vitiligo }\end{array}$ \\
\hline $\begin{array}{l}\text { Taneja } \\
\text { et al. [22] }\end{array}$ & 2020 & $\begin{array}{l}\text { Cross- } \\
\text { sectional }\end{array}$ & 54 & $\begin{array}{l}\text { To investigate } \\
\text { homocysteine } \\
\text { levels and lipid } \\
\text { risk factors in } \\
\text { vitiligo }\end{array}$ & $\begin{array}{l}\text { Increased levels of LDL, homocysteine } \\
\text { and LDL/HDL. Decreased level of HDL }\end{array}$ & $\begin{array}{l}\text { Increased homocysteine levels } \\
\text { may be a precipitating factor in } \\
\text { the pathogenesis of vitiligo. } \\
\text { Increased lipid levels may be } \\
\text { due to abnormal metabolic } \\
\text { processes }\end{array}$ \\
\hline $\begin{array}{l}\text { Tsai et } \\
\text { al. [23] }\end{array}$ & 2019 & $\begin{array}{l}\text { Review } \\
\text { article }\end{array}$ & 1,215 & $\begin{array}{l}\text { To investigate } \\
\text { the role of } \\
\text { homocysteine, } \\
\text { folate, and } \\
\text { vitamin B12 } \\
\text { levels in vitiligo }\end{array}$ & $\begin{array}{l}\text { Increased level of homocysteine, } \\
\text { decreased level of B12, and folate } \\
\text { levels not significantly raised }\end{array}$ & $\begin{array}{l}\text { Vitiligo was associated with } \\
\text { higher homocysteine and lower } \\
\text { vitamin B12 levels, which } \\
\text { correlate with disease activity }\end{array}$ \\
\hline $\begin{array}{l}\text { Singh et } \\
\text { al. [24] }\end{array}$ & 2011 & $\begin{array}{l}\text { Case } \\
\text { control }\end{array}$ & 30 & $\begin{array}{l}\text { To investigate } \\
\text { the association } \\
\text { between } \\
\text { homocysteine } \\
\text { levels and } \\
\text { vitiligo }\end{array}$ & $\begin{array}{l}\text { Increased homocysteine levels in } \\
\text { patients with vitiligo }\end{array}$ & $\begin{array}{l}\text { Increased homocysteine levels } \\
\text { may be the cause for vitiligo in } \\
\text { predisposed individuals }\end{array}$ \\
\hline
\end{tabular}

\section{TABLE 2: Studies reporting the role of cytokines and homocysteine.}

HTN: hypertension; ROS: reactive oxygen species; HOMA-IR: homeostatic model assessment of insulin resistance; LDL: low-density lipoprotein; HDL: high-density lipoprotein; SBP: systolic blood pressure; NE: nor-epinephrine; E: epinephrine; NMN: nor-metanephrine; MN: metanephrine; HVA: homovanillic acid; 5-HIAA: 5-hydroxyindoleacetic acid 


\section{Cureus}

Clinical Outcomes

Metabolic syndrome results in a significant cardiovascular outcome, which is a widely studied aspect of the disorder. Ahmad et al. showed myocardial infarction as a possible outcome of vitiligo, which they attributed to elevated levels of IL-17 and decreased levels of vitamin D and calcium [7]. A study by Yuan et al. showed the prevalence of thyroid disorders in vitiligo such as overt hyperthyroidism and subclinical hyperthyroidism [25].

Biondi et al. showed that thyroid disorders were associated with various metabolic abnormalities including type 1 diabetes, type 2 diabetes, and metabolic syndrome. They explained that thyroid hormones affect food intake, resting energy expenditure, and consequently, lead to metabolic alteration [26]. Chang et al. showed a significant association of vitiligo with both type 1 and type 2 diabetes [27].

A study by Mubki et al. found a higher prevalence of increased fasting plasma glucose levels in patients with vitiligo, which was similar to the findings of another study by Gopal et al., who concluded that the prevalence of diabetes mellitus was statistically significant in patients with vitiligo [4,5]. A study by $\mathrm{Al}$ Houssein et al. found a significantly increased risk of diabetes and dyslipidemia and an increased risk of developing obesity and renal injuries in vitiligo patients [28]. Tanacan et al. also found an increased frequency of metabolic syndrome in patients with vitiligo [1]. Sharma et al., in their study, found the prevalence of impaired glucose tolerance and significantly high levels of triglyceride and low levels of HDL in patients than in controls [29]. Onan et al. found remarkably higher levels of insulin and triglyceride levels in patients with vitiligo. However, no significant increase was found in the prevalence of insulin resistance or metabolic syndrome in their study [30]. Increased prevalence of vitiligo in type 2 diabetes patients has also been seen in some studies [31,32].

Role of Simvastatin as an Immunomodulator in Vitiligo

Simvastatin, a potent statin drug used widely in dyslipidemia and cardiovascular diseases, also possesses antioxidant and anti-inflammatory properties by its action on $\mathrm{CD} 8+\mathrm{T}$ cells. It inhibits the production of proinflammatory cytokines, which is an important factor in the pathogenesis of vitiligo, as discussed above [10]. A small clinical trial conducted by Vanderweil et al. found topical simvastatin to be more useful than the systemic form, citing potential adverse effects of the systemic form [33]. Zhang et al. found that oral simvastatin was safe to be used in vitiligo; however, their study concluded that the drug might not be effective in the treatment of vitiligo [34]. A case report by Noel et al. described repigmentation in a vitiligo patient by treating with a high dose of simvastatin, the effect of which they attributed to the immunomodulation by inhibition of CD8+ T cells in melanocytes by IFN- $\gamma$ [35].

Similarly, an in-vitro study by Chang et al. found that simvastatin was able to ameliorate $\mathrm{H}_{2} \mathrm{O}_{2}$-induced oxidative damage in human melanocytes by preventing the intracellular accumulation of ROS. They explained that it was probably due to the activity of antioxidant enzymes potentiated by the drug by activating nuclear factor erythroid 2- related factor, which contributed to mutual enhancement between mitogen-activated protein kinase pathway and p62. Their study showed that simvastatin protected cells from $\mathrm{H}_{2} \mathrm{O}_{2}$-induced cell apoptosis and ROS accumulation, highlighting the therapeutic potential of simvastatin in vitiligo [8]. It also blocks PI3k/Akt signal transduction pathway involved in T cell production. By virtue of these properties, patients with vitiligo can benefit from simvastatin as an immunomodulator and help prevent metabolic complications such as metabolic syndrome [9]. Figure 3 shows the mechanism of action of simvastatin. 


\section{Cureus}

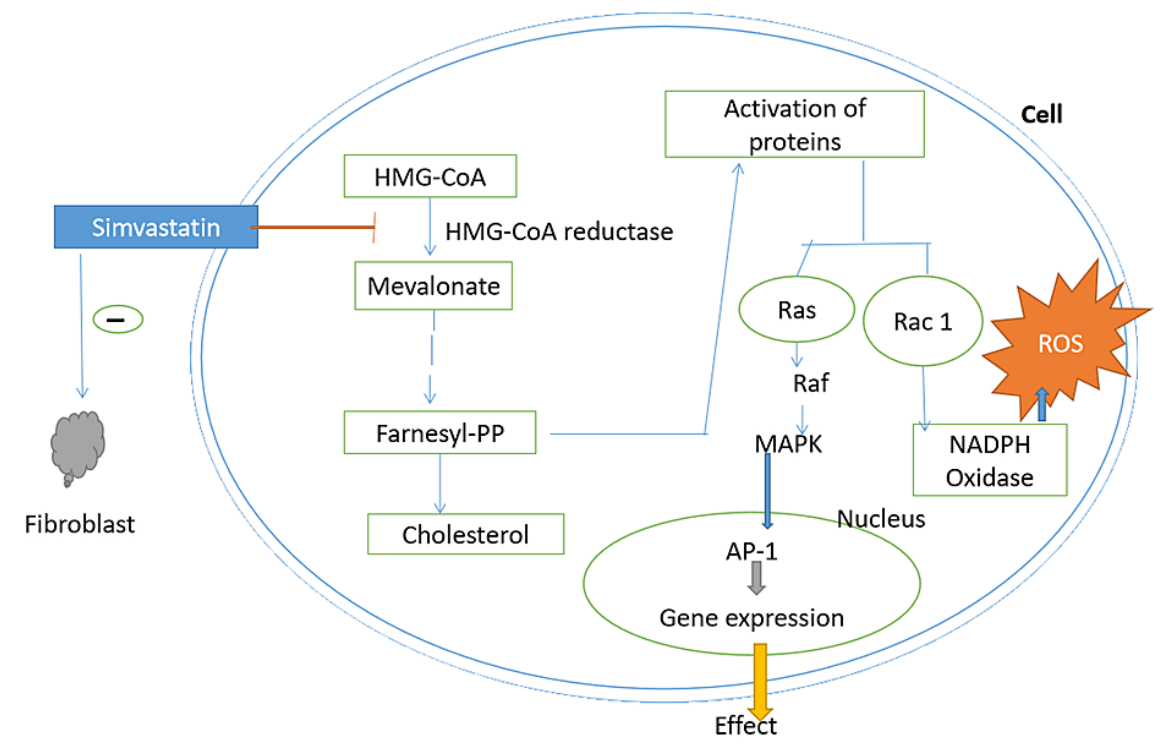

FIGURE 3: Mechanism of action of simvastatin.

AP-1: activator protein; Farnesyl-PP: farnesyl pyrophosphate; HMG-CoA: 3-hydroxy-3-methylglutaryl coenzyme A; MAPK: mitogen-activated protein kinase; NADP: nicotinamide adenine dinucleotide phosphate; ROS: reactive oxygen species

Table 3 summarizes the role of simvastatin in treatment of vitiligo.

\begin{tabular}{|c|c|c|c|c|c|}
\hline Author & Year & $\begin{array}{l}\text { Type of } \\
\text { study }\end{array}$ & $\begin{array}{l}\text { No. of } \\
\text { patients }\end{array}$ & Purpose of study & Conclusion \\
\hline $\begin{array}{l}\text { Chang et } \\
\text { al. [8] }\end{array}$ & 2017 & $\begin{array}{l}\text { In-vitro } \\
\text { experiment }\end{array}$ & - & $\begin{array}{l}\text { To study the protective role of simvastatin } \\
\text { against oxidative stress on human melanocytes }\end{array}$ & $\begin{array}{l}\text { Defends against oxidative stress by } \\
\text { stimulating Nrf2 }\end{array}$ \\
\hline $\begin{array}{l}\text { Niezgoda } \\
\text { et al. [10] }\end{array}$ & 2019 & RCT & 24 & To study the influence of simvastatin in vitiligo & - \\
\hline $\begin{array}{l}\text { Vanderweil } \\
\text { et al. [33] }\end{array}$ & 2017 & RCT & 15 & $\begin{array}{l}\text { To investigate the role of simvastatin in the } \\
\text { treatment of vitiligo }\end{array}$ & $\begin{array}{l}\text { Oral form may not be beneficial in the } \\
\text { treatment of vitiligo }\end{array}$ \\
\hline $\begin{array}{l}\text { Zhang et } \\
\text { al. [34] }\end{array}$ & 2021 & RCT & 5 & $\begin{array}{l}\text { To assess the efficacy of simvastatin in the } \\
\text { treatment of vitiligo }\end{array}$ & $\begin{array}{l}\text { Oral simvastatin is safe but may not be } \\
\text { effective in the treatment of vitiligo }\end{array}$ \\
\hline $\begin{array}{l}\text { Noel et al. } \\
\text { [35] }\end{array}$ & 2004 & $\begin{array}{l}\text { Case } \\
\text { report }\end{array}$ & 1 & $\begin{array}{l}\text { To assess the role of high-dose simvastatin as } \\
\text { an immunomodulator in vitiligo }\end{array}$ & $\begin{array}{l}\text { Simvastatin can be used as an } \\
\text { immunomodulator in vitiligo }\end{array}$ \\
\hline
\end{tabular}

TABLE 3: Studies on the role of simvastatin in the treatment of vitiligo.

RCT: randomized controlled trial; Nrf2: nuclear factor erythroid 2-related factor 2

In our study, we came across the difference in studies collected for the review. Some studies directly established the association between vitiligo and metabolic syndrome, while other studies showed an association between vitiligo and one of the component disorders of metabolic syndrome. The other aspect of the study was that it could not ensure an established association between the disorders, which opens the possibility for more and better evaluation and research.

Limitations

Despite the availability of various resources and facilities for data collection, most of the articles were inaccessible either due to availability on a payment basis or institutional inaccessibility or citing confidentiality. Most of the data collected were observational studies based on a smaller sample size. Moreover, there was the unavailability of large randomized controlled trials or case-control studies 
regarding the use of simvastatin as an immunomodulator in vitiligo and its potential benefits in preventing metabolic complications. Our systematic review will hopefully be beneficial for further exploration on this topic.

\section{Conclusions}

The data collected for the analysis of the association between vitiligo and metabolic syndrome showed hopeful results. Some studies addressed the association between the disorders, whereas others showed the association between vitiligo and one of the constituent disorders of metabolic syndrome, that is, insulin resistance or hypertension or dyslipidemia, instead of metabolic syndrome as a whole. Based on the reviewed articles, we found that some factors such as oxidative stress and pro-inflammatory cytokines play an important role in the development of both disorders. Oxidative stress leads to the generation of ROS, which destroys melanocytes via apoptosis. Reduced number of melanocytes in adipose tissue leads to insulin resistance and lipid abnormalities. Increased levels of cytokines lead to insulin resistance by phosphorylation of insulin receptors, which renders them resistant. Increased levels of homocysteine and catecholamines also contribute to the process. It is also noteworthy to acknowledge simvastatin's role in preventing oxidative stress and cytokine-mediated complications in patients with vitiligo. However, this property of simvastatin is not much explored. Our systematic review will hopefully pave the way for the conduction of large-scale prospective studies to establish the relation between vitiligo and metabolic syndrome along with the direction of the association between the two and, hopefully, will help in exploring the benefits of simvastatin as an antioxidant therapy to prevent the development of metabolic complications.

\section{Additional Information \\ Disclosures}

Conflicts of interest: In compliance with the ICMJE uniform disclosure form, all authors declare the following: Payment/services info: All authors have declared that no financial support was received from any organization for the submitted work. Financial relationships: All authors have declared that they have no financial relationships at present or within the previous three years with any organizations that might have an interest in the submitted work. Other relationships: All authors have declared that there are no other relationships or activities that could appear to have influenced the submitted work.

\section{References}

1. Tanacan E, Atakan N: Higher incidence of metabolic syndrome components in vitiligo patients: a prospective cross-sectional study. An Bras Dermatol. 2020, 95:165-72. 10.1016/j.abd.2019.07.006

2. Namazi MR, Rouhani S, Moarref A, Kiani M, Tabei SS, Hadibarhaghtalab M: Vitiligo and rise in blood pressure - a case-control study in a referral dermatology clinic in southern Iran. Clin Cosmet Investig Dermatol. 2020, 13:425-30. 10.2147/CCID.S257022

3. Ataş H, Gönül M: Increased risk of metabolic syndrome in patients with vitiligo . Balkan Med J. 2017, 34:21925. 10.4274/balkanmedj.2016.1005

4. Mubki T, Alissa A, Mulekar S, Albargawi S, Youssef M, AlJasser M: Association of vitiligo with anemia, vitamin B12 deficiency, diabetes mellitus, and thyroid dysfunction in Saudi Arab patients: a case control study. J Dermatol Dermatol Surg. 2017, 21:72-6. 10.1016/j.jdds.2017.06.001

5. Gopal KV, Rao GR, Kumar YH: Increased prevalence of thyroid dysfunction and diabetes mellitus in Indian vitiligo patients: a case-control study. Indian Dermatol Online J. 2014, 5:456-60. 10.4103/2229-5178.142493

6. Alexander CM, Landsman PB, Teutsch SM, Haffner SM, Third National Health and Nutrition Examination Survey (NHANES III); National Cholesterol Education Program (NCEP): NCEP-defined metabolic syndrome, diabetes, and prevalence of coronary heart disease among NHANES III participants age 50 years and older. Diabetes. 2003, 52:1210-4. 10.2337/diabetes.52.5.1210

7. Ahmed Abdel Rahman SH, Hussein MS, Mansour AI: Are patients with vitiligo more prone to myocardial infarction?: a case-control study. J Clin Aesthet Dermatol. 2019, 12:28-31.

8. Chang Y, Li S, Guo W, et al.: Simvastatin protects human melanocytes from H2O2-induced oxidative stress by activating Nrf2. J Invest Dermatol. 2017, 137:1286-96. 10.1016/j.jid.2017.01.020

9. Namazi MR: Statins: novel additions to the dermatologic arsenal? . Exp Dermatol. 2004, 13:337-9. 10.1111/j.0906-6705.2004.00208.x

10. Niezgoda A, Winnicki A, Kosmalski T, Kowaliszyn B, Krysiński J, Czajkowski R: The evaluation of vitiligous lesions repigmentation after the administration of atorvastatin calcium salt and simvastatin-acid sodium salt in patients with active vitiligo (EVRAAS), a pilot study: study protocol for a randomized controlled trial. Trials. 2019, 20:78. 10.1186/s13063-018-3168-4

11. Moher D, Liberati A, Tetzlaff J, Altman DG; PRISMA Group: Preferred reporting items for systematic reviews and meta-analyses: the PRISMA statement. PLoS Med. 2009, 6:1000097. 10.1371/journal.pmed.1000097

12. Azzazi Y, Mostafa WZ, Sayed KS, et al.: Support for increased cardiovascular risk in non-segmental vitiligo among Egyptians: a hospital-based, case-control study [Online ahead of print]. Pigment Cell Melanoma Res. 2020, 10.1111/pcmr.12941

13. Sinha PK, Nigam P, Swain JP: Association of metabolic syndrome with vitiligo- a case control study . J Evolution Med Dent Sci. 2019, 8:2783-6. 10.14260/jemds/2019/604

14. Koca R, Armutcu F, Altinyazar HC, Gürel A: Oxidant-antioxidant enzymes and lipid peroxidation in generalized vitiligo. Clin Exp Dermatol. 2004, 29:406-9. 10.1111/j.1365-2230.2004.01524.x 
15. Khan R, Satyam A, Gupta S, Sharma VK, Sharma A: Circulatory levels of antioxidants and lipid peroxidation in Indian patients with generalized and localized vitiligo. Arch Dermatol Res. 2009, 301:731-7. 10.1007/s00403-009-0964-4

16. Bhatti JS, Bhatti GK, Reddy PH: Mitochondrial dysfunction and oxidative stress in metabolic disorders - a step towards mitochondria based therapeutic strategies. Biochim Biophys Acta Mol Basis Dis. 2017, 1863:1066-77. 10.1016/j.bbadis.2016.11.010

17. Mitra S, De Sarkar S, Pradhan A, et al.: Levels of oxidative damage and proinflammatory cytokines are enhanced in patients with active vitiligo. Free Radic Res. 2017, 51:986-94. 10.1080/10715762.2017.1402303

18. Karadag AS, Tutal E, Ertugrul DT: Insulin resistance is increased in patients with vitiligo . Acta Derm Venereol. 2011, 91:541-4. 10.2340/00015555-1141

19. Pietrzak A, Bartosińska J, Dybiec E, Chodorowska G, Krasowska D, Hercogova J, Lotti T: Hepato-splenic and lipid profile abnormalities--do they exist in children affected with vitiligo?. Acta Dermatovenerol Croat. 2014, 22:19-25.

20. Cucchi ML, Frattini P, Santagostino G, Orecchia G: Higher plasma catecholamine and metabolite levels in the early phase of nonsegmental vitiligo. Pigment Cell Res. 2000, 13:28-32. 10.1034/j.16000749.2000.130106.x

21. Orecchia G, Frattini P, Cucchi ML, Santagostino G: Normal-range plasma catecholamines in patients with generalized and acrofacial vitiligo: preliminary report. Dermatology. 1994, 189:350-3. 10.1159/000246877

22. Taneja K, Taneja J, Kaur C, Patel S, Haldar D: Lipid risk factors in vitiligo: homocysteine the connecting link?. Clin Lab. 2020, 66:10. 10.7754/Clin.Lab.2020.200120

23. Tsai TY, Kuo CY, Huang YC: Serum homocysteine, folate, and vitamin B12 levels in patients with vitiligo and their potential roles as disease activity biomarkers: a systematic review and meta-analysis. J Am Acad Dermatol. 2019, 80:646-54. 10.1016/j.jaad.2018.08.029

24. Singh S, Singh U, Pandey SS: Increased level of serum homocysteine in vitiligo . J Clin Lab Anal. 2011, 25:110-2. 10.1002/jcla.20442

25. Yuan J, Sun C, Jiang S, et al.: The prevalence of thyroid disorders in patients with vitiligo: a systematic review and meta-analysis. Front Endocrinol (Lausanne). 2019, 9:803. 10.3389/fendo.2018.00803

26. Biondi B, Kahaly GJ, Robertson RP: Thyroid dysfunction and diabetes mellitus: two closely associated disorders. Endocr Rev. 2019, 40:789-824. 10.1210/er.2018-00163

27. Chang HC, Lin MH, Huang YC, Hou TY: The association between vitiligo and diabetes mellitus: a systematic review and meta-analysis. J Am Acad Dermatol. 2019, 81:1442-5. 10.1016/j.jaad.2019.06.022

28. Al Houssien AO, Al Houssien RO, Al Ajroush W, Al Kahtani HS: Chronic diseases among vitiligo patients. A case control study. Saudi Med J. 2017, 38:400-4. 10.15537/smj.2017.4.17551

29. Sharma YK, Bansal P, Menon S, Prakash N: Metabolic syndrome in vitiligo patients among a semi-urban Maharashtrian population: a case control study. Diabetes Metab Syndr. 2017, 11:77-80. 10.1016/j.dsx.2016.12.009

30. Onan DT, Tantoglu BH, Artuz F, et al.: The relationship of vitiligo with insulin resistance and metabolic syndrome [Article in Turkish]. Turkiye Klinikleri J Med Sci. 2018, 38:241-7. 10.5336/medsci.2018-60404

31. Afkhami-Ardekani M, Ghadiri-Anari A, Ebrahimzadeh-Ardakani M, Zaji N: Prevalence of vitiligo among type 2 diabetic patients in an Iranian population. Int J Dermatol. 2014, 53:956-8. 10.1111/ijd.12148

32. Raveendra L, Hemavathi RN, Rajgopal S: A study of vitiligo in type 2 diabetic patients . Indian J Dermatol. 2017, 62:168-70. 10.4103/ijd.IJD_360_16

33. Vanderweil SG, Amano S, Ko WC, et al.: A double-blind, placebo-controlled, phase-II clinical trial to evaluate oral simvastatin as a treatment for vitiligo. J Am Acad Dermatol. 2017, 76:150-1. 10.1016/j.jaad.2016.06.015

34. Zhang S, Zdravković TP, Wang T, Liu Y, Jin H: Efficacy and safety of oral simvastatin in the treatment of patients with vitiligo. J Investig Med. 2021, 69:393-6. 10.1136/jim-2020-001390

35. Noël M, Gagné C, Bergeron J, Jobin J, Poirier P: Positive pleiotropic effects of HMG-CoA reductase inhibitor on vitiligo. Lipids Health Dis. 2004, 3:7. 10.1186/1476-511X-3-7 